\title{
Litter priming and trenching greatly affect soil respiration in a mature subtropical evergreen broadleaf forest in Southwestern China
}

\author{
J. J. WANG ${ }^{1,2}$, L. M. LAI $I^{1,2}$, X. C. ZHAO ${ }^{1,2}$, L. H. JIANG ${ }^{1,2}$, Y. J. WANG ${ }^{1,2}$, J. H. ZHOU ${ }^{1,2}$, \\ F. $\mathrm{WANG}^{3}$, C. $\mathrm{ZHANG}^{3}$, Y. R. ZHENG ${ }^{1}$ \\ ${ }^{1}$ Beijing Botanical garden \\ Key Laboratory of Resource Plants \\ West China Subalpine Botanical Garden \\ Institute of Botany CAS \\ 100093, China, Beijing \\ ${ }^{2}$ University of Chinese Academy of Sciences \\ 100039, Beijing, China \\ ${ }^{3}$ West China Subalpine Botanical garden \\ Institute of Botany $\mathrm{CAS}$ \\ 611843, China, Dujiangyanyan \\ E-mail: zhengyr@ibcas.ac.cn
}

Статья поступила 22.11.2014

Принята к печати 30.01.2015

\begin{abstract}
Global warming will stimulate primary production, which is likely to drive shifts in litter production and lead to an increase in carbon (C) inputs to soil. However, the effects of such changes on soil $\mathrm{C}$ cycling in subtropical forests remain largely unknown. In a typical subtropical evergreen broadleaved forest in Southwestern China we conducted a controlled experiment that included addition and removal of litter, and trenching. Annual soil respiration in control, trenching, litter addition, and litter removal treatments were $1083.47,521.50,1363.30$, and $896.15 \mathrm{~g} \mathrm{C} \mathrm{m}^{-2} \mathrm{y}^{-1}$, respectively. Soil respiration was significantly related to temperature in all treatments, but was independent of soil moisture, except in control plots. $\mathrm{Q}_{10}$ values in control, trenching, litter addition, and litter removal treatments were 3.46, 6.36, 2.72, and 4.85, respectively. Litter addition reduced $\mathrm{Q}_{10}$, but litter removal and trenching increased it. Average heterotrophic soil respiration produced $\mathrm{C}$ in the amount equivalent to $48 \%$ of the efflux from the soil. Soil respiration in the litter addition treatment was $25 \%$ higher than in the control treatment; this increase is about $8 \%$ larger than the $17 \%$ decrease in soil respiration caused by litter removal. This implies a priming effect on soil respiration. Our results suggest that increases in litter production in response to human disturbances and global warming could have rapid and important consequences on soil respiration in subtropical evergreen broadleaved forests.
\end{abstract}

Key words: soil respiration, heterotrophic respiration, litter, litter addition, litter removal.

(ㄷ) Wang J. J., Lai L. M., Zhao X. C., Jiang L. H., Wang Y. J., Zhou J. H., Wang F., Zhang C., Zheng Y. R., 2015 
Soil respiration $\left(R_{S}\right)$ is acknowledged to be the second largest source of carbon (C) flux between terrestrial ecosystems and the atmosphere, and it strongly affects the global C cycle [Raich, Schlesinger, 1992; Schlesinger, Andrews, 2000]. The magnitude of $\mathrm{C}$ flux from soil respiration is approximately 11 -fold greater than fossil fuel and deforestation sources combined [Marland et al., 2000], therefore even small changes in total fluxes will influence atmospheric chemistry and heat balance. Considerable effort has been devoted to the quantification of fluxes of carbon dioxide $\left(\mathrm{CO}_{2}\right)$ from soils [Schimel et al., 2000; Houghton, Goodale, 2002], however, there remains a great deal of uncertainty about it [Ryan, Law, 2005; Trumbore, 2006].

Soil respiration is often related to soil temperature [Davidson et al., 2006], soil moisture, and their interaction [Hanson et al., 2000]. The simple empirical temperature dependence equation can generally be described as exponential " $\mathrm{Q}_{10}$ " (the change in reaction rate with a $10^{\circ} \mathrm{C}$ temperature increase), and has been widely proved to have the predictive capacity to accurately model $R_{S}$ at individual sites and on a global scale; however, sometimes it needs to be amended by a scalar, depending on water availability [Raich, Schlesinger, 1992; Hibbard et al., 2005; Davidson et al., 2006]. Rapid water input may cause a large increase in $R_{S}$, described as the "Birch effect" [Lee et al., 2004], while it is lower in dry soils where low soil water content reduces respiration by limiting microbial contact with available substrate [Baldocchi et al., 2006]. However, the correlation between soil respiration and environmental conditions has been challenged by several recent studies [Janssens et al., 2001; Bhupinderpal-Singh et al., 2003; Hibbard et al., 2005], suggesting that such factors as aboveground photosynthetic activity and soil organic carbon storage and input (from the sources like litterfall and root turnover) may impact $R_{S}$ as strongly or more strongly than soil temperature and moisture [Bhupinderpal-Singh et al., 2003]. While the underlying mechanisms controlling $R_{S}$ are not totally clear, it is important to attempt to better understand these mechanisms, which will significantly influence our comprehensive understanding of the carbon balance in terrestrial ecosystems.
Aboveground plant litter fluxes are strongly correlated with $R_{S}$ on a global scale [Raich, Schlesinger, 1992], and locally, litter manipulations have shown to have strong effects on $R_{S}$ [Fontaine et al., 2004; Sulzman et al., 2005; Sayer et al., 2007; Leff et al., 2012]. As aboveground litter provides organic carbon and nutrients to the soil for root and microbial growth [Sayer, 2006; Sayer et al., 2006], it also can cause a release of dissolved organic carbon which can cause a priming effect [Park et al., 2002; Kalbitz et al., 2007]. It is likely that changes in aboveground litter production will have significant consequences for $R_{S}$ [Sayer et al., 2007], and it is important to elucidate how predicted changes in litter inputs and removal might affect $R_{S}$ in various ecosystems [Townsend et al., 2011].

Soil respiration is usually separated into two components: heterotrophic respiration and autotrophic respiration [Hanson et al., 2000]. Here, heterotrophic respiration is the decomposition of complex compounds, such as litter and soil organic matter [Högberg et al., 2009], and autotrophic respiration is that of live roots and closely associated microorganisms that are dependent on the flux of recent photosynthate [Högberg, Read, 2006]. Heterotrophic and autotrophic respiration alone releases into the atmosphere approximately $98 \pm 12 \mathrm{Pg}$ of $\mathrm{C}$ per year [Lamberty, Thomson, 2010]. The two components of $R_{S}$ may respond differently to environmental changes, which may have profound implications for the ecosystem $\mathrm{C}$ balance. Therefore, it is necessary to define the variables controlling each component to help us better understand the effects of climate change on $\mathrm{C}$ cycling [Ohashi et al., 2000; Bond-Lamberty et al., 2004]. Currently, trenched plots are extensively used in studies of $R_{S}$ because of their simplicity and low cost [Hanson et al., 2000]. This method terminates all root functions and has been extensively used to separate respiration of roots and associated rhizospheric microbes from that of soil heterotrophs [Schaefer et al., 2010].

The subtropical forest in Southern China represents about one-third of the total forested area of China; it has a unique subtropical monsoon climate with abundance of rainfall, heat and light [Tang et al., 2006]. The subtropical evergreen broadleaved forest is distributed 
across over 10 latitudes in China and is the largest and the most typical evergreen broadleaved forest in the world; large portions of landscapes at the same latitude in other areas of the world are covered by deserts [Sheng et al., 2010]. Despite the importance of this forest in national $\mathrm{C}$ budgets and in the climatic system, $R_{S}$ of the system is poorly understood and there are limited accurate estimates of the forest $C$ budget. Therefore, separating $R_{S}$ components to understand their determinants is very important.

In this study, we conducted an experiment consisting of a trenching plot, and monthly litter removal and litter addition treatments in a subtropical evergreen broadleaved forest. Our specific objectives were to (1) separate heterotrophic and autotrophic respiration; (2) quantify annual fluxes of $R_{S}$ components and their relative contributions in the forest ecosystem; (3) understand the $R_{S}$ dynamics under different disturbances in a large area of the subtropical forest in East Asia.

\section{MATERIALS AND METHODS}

\section{Site description and experiment design}

The research site is located near the West China Subalpine Botanical Garden, Institute Of Botany, Chinese Academy of Science, Dujiangyan, in the province of Sichuan, Western China $\left(30^{\circ} 44^{\prime} \mathrm{N}, 103^{\circ} 27^{\prime} \mathrm{E}\right)$. The site receives an annual average of $1243 \mathrm{~mm}$ of precipitation, and the monsoon climate produces the wet season from May through October and the dry season from November through April. The mean annual temperature is $15.2^{\circ} \mathrm{C}$. This relatively undisturbed forest is dominated by the subtropical evergreen broad-leaved species Cyclobalanopsis oxyodon, Lithocarpus harlandii, Phoebe zhennan, Symplocos laurina, Castanopsis carlesi, Pittosporaceae xylocarpum, Aphananthe aspera, and Ficus henryi. On the experimental plots, tree density was $1895 \mathrm{ha}^{-1}$, mean diameter at breast height was $15 \mathrm{~cm}$ (ranged from 1 to 38.3), and mean tree height was $10.2 \mathrm{~m}$.

A random design of the three treatments (root trenching, litter removal and litter addition) with three replications was used to separate the effects of above- and belowground carbon inputs on $\mathrm{R}_{\mathrm{S}}$ from those of root uptake of nutrients and water. Three permanent fixed plots $20 \times 30 \mathrm{~m}$ were set up in the subtropical forest, and within each plot, four $1 \times 1 \mathrm{~m}$ subplots were randomly assigned as control (untrenched and litter keeping, UTC), root trenching and litter keeping (TL), untrenched and litter removal (UTL-), and untrenched and litter addition (UTL+) in the forest ecosystem.

The trenches were cut to a depth of $50 \mathrm{~cm}$ because the main root biomass is vertically distributed in the $0-50 \mathrm{~cm}$ of soil layer [Peng, Hao, 2005]. The trenches were lined with polyethylene sheets at the sides, but not at the bottom and were repacked carefully with the soil. For UTL-, all litter and organic humus above the mineral soil were carefully removed to eliminate any effects of previous aboveground litter on $\mathrm{R}_{\mathrm{S}}$ rates. For UTL+, all litter and organic humus collected from each $1 \times 1 \mathrm{~m}$ subplot of UTL- were added to each $1 \times 1 \mathrm{~m}$ subplot of UTL+. Polyvinyl chloride (PVC) collars (20 cm inside diameter $\times 6 \mathrm{~cm}$ height) were randomly installed for the measurement of $R_{S}$ in each subplot. Collars were kept in the same locations for continuity throughout the study period. Field measurements were usually conducted monthly, in the beginning of the month, from August 2009 to November 2010.

\section{Measurements protocols}

2.1. Soil respiration. Soil respiration was measured using an automated soil $\mathrm{CO}_{2}$ flux system (Li-8100, LI-COR Inc., Lincoln, NE, USA) equipped with the $20 \mathrm{~cm}$ survey chamber (Model 8100-103). Before sampling, plants inside these chamber bases were clipped, and any regrowth was removed prior to obtaining each measurement. To avoid any pulse effect of precipitation on $R_{S}$, measurements were performed on the third day after a rainfall. All $R_{S}$ measurements were made between 09:00 and 11:00 (local time), when $R_{S}$ is approximately representative of daily average $R_{S}$ [Tang et al., 2006]. Each measurement took 3-4 min to obtain.

2.2. Soil temperature and water content. At the time of $R_{S}$ measurement, a probe equipped with the LI-8100 system was used to auto- 
matically measure soil temperature and soil moisture at a depth of 10 and $0-5 \mathrm{~cm}$, respectively.

2.3. Litter production. Litter was collected from $121-\mathrm{m}^{2}$ traps at permanent random locations in each $20 \times 30 \mathrm{~m}$ plot from January 2010 to December 2010. Litter was dried to a constant weight at $80{ }^{\circ} \mathrm{C}$. Litter $\mathrm{C}$ content was calculated as $0.48 \times$ litter biomass [Wieder et al., 2009].

\section{Parameters calculations}

Trenching cuts off the supply of aboveground photosynthesis to roots and causes rapid root mortality. Therefore, only heterotrophic respiration $\left(R_{H}\right)$ persists after the roots have been disabled, and autotrophic respiration $\left(\mathrm{R}_{\mathrm{A}}\right)$ is estimated as the difference in $R_{S}$ between the trenching and litter keeping treatments and control. We calculated the annual fluxes of $R_{H}$ and $\mathrm{R}_{\mathrm{A}}\left(\mathrm{g} \mathrm{C} \mathrm{m}^{-2} \mathrm{yr}^{-1}\right)$ and relative contribution of $R_{A}$ to total soil surface $\mathrm{CO}_{2}$ flux $\left(\mathrm{R}_{\mathrm{C}}, \%\right)$ as:

$$
\begin{gathered}
R_{A}=R_{S}-R_{H}, \\
R_{C}=R_{A} / R_{S} \times 100,
\end{gathered}
$$

where $R_{S}$ is the total soil surface $C_{2}$ flux. The relationship between seasonal $R_{S}$, soil temperature, and soil moisture was examined using linear and nonlinear regression models:

$$
\begin{gathered}
R=a e^{b T}, \\
R=m W+n, \\
R=a e^{b T} W^{c},
\end{gathered}
$$

where $R$ is either $R_{A}$ or measured $R_{H}$ ( $\mu$ mol$\left.\mathrm{CO}_{2} \mathrm{~m}^{-2} \mathrm{~s}^{-1}\right), \mathrm{T}$ is the soil temperature $\left(1^{\circ} \mathrm{C}\right)$ at a depth of $10 \mathrm{~cm}, \mathrm{~W}$ is volumetric soil moisture $\left(\mathrm{cm}^{3} \mathrm{~cm}^{-3}\right)$, and $\mathrm{a}, \mathrm{b}, \mathrm{c}, \mathrm{m}$, and $\mathrm{n}$ are constants fitted by the least-square technique.

The $Q_{10}$ value, the increase in the rate of $R_{S}$ when the soil temperature increases by $10{ }^{\circ} \mathrm{C}$, which represents the temperature sensitivity of $R_{S}$, was calculated as follows:

$$
\mathrm{Q}_{10}=\mathrm{e}^{10 \mathrm{~b}} \text {. }
$$

\section{Statistical test}

The annual $R_{S}$ in each treatment was estimated by extrapolating measurement data. The significance of all regression equations was analyzed using the $F$-test at a $5 \%$ level. The soil respiration values in UTL+, UTC, UTL-, and TL treatments were analyzed using oneway ANOVA. If significant differences were found, the Duncan test was used to determine mean differences between treatments. All statistical analyses, including the test for homogeneity of variance, were performed using the SPSS 17.0 package (SPSS 2000).

\section{RESULTS AND DISCUSSION}

\section{Environment factors and litter inputs}

Soil temperatures varied seasonally from approximately 5 to $22{ }^{\circ} \mathrm{C}$, and there were no significant differences in temperature between treatments (Fig. 1). Maximum temperatures occurred in July, and minimum temperatures in January. Annual soil moisture at a depth of 0-5 cm varied significantly between the treatments; annual soil moisture in TL, UTL-, UTC, and UTL+ was 31.22, 27.55, 31.45, and $29.26 \mathrm{~cm}^{3} \mathrm{~cm}^{-3}$ (Fig. 2), respectively. Soil moisture of UTL- was lower than the others' treatments. Annual average litterfall was $863.98 \mathrm{~g} \mathrm{~m}^{-2} \mathrm{yr}^{-1}$ in the UTC plots; maximum litterfall in UTC plots occurred in May, and minimum litterfall in January (Fig. 3).

\section{Soil respiration in the litter addition and removal treatments}

The mean annual $R_{S}$ for the UTC, UTL-, and UTL+ was 1083.47, 896.15 and

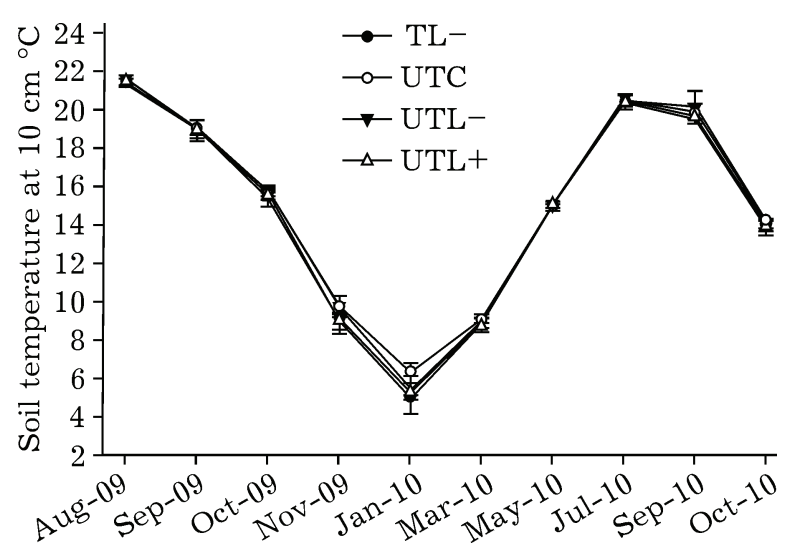

Fig. 1. Temporal changes of soil temperature (at $10 \mathrm{~cm}$ depth) (mean $\pm \mathrm{SE}$ ) on the treatment plots 


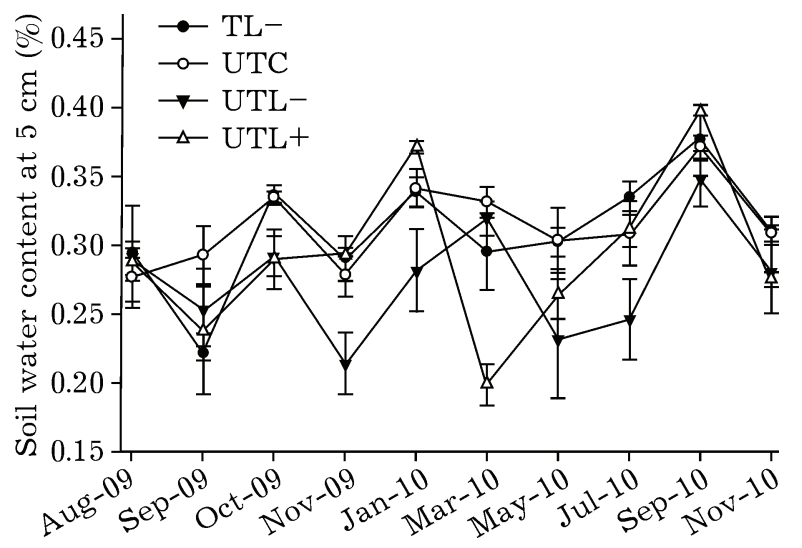

Fig. 2. Temporal changes of soil moisture content (at $5 \mathrm{~cm}$ depth) (mean $\pm \mathrm{SE}$ ) on the treatment plots

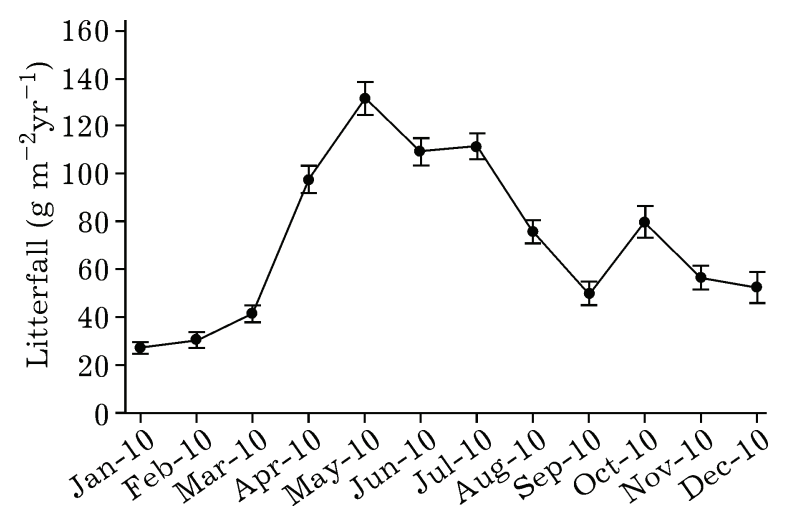

Fig. 3. The litterfall measured in relation to the control plot in the subtropical forest, southwest China, from August 2009 to December 2010

$1363.30 \mathrm{~g} \mathrm{C} \mathrm{m}^{-2} \mathrm{y}^{-1}$, respectively. $\mathrm{R}_{\mathrm{S}}$ varied significantly seasonally, and was high in summer and low in winter. Litter manipulation significantly affected $R_{\mathrm{S}}$. Generally, the UTL+ treatment had the highest $R_{S}$; in UTL,$+ R_{S}$ was 25.83 $\%$ higher than that of the control (Fig. 4). The increase in $R_{S}$ induced by litter addition was higher than the decrease in $R_{S}$ induced by litter removal. $R_{S}$ in the UTL- treatment was $17.29 \%$ lower than that of the control.

\section{Soil respiration in the trenched and untrenched treatments}

The mean annual $R_{\mathrm{S}}$ in TL and UTC was 521.50 and $1083.47 \mathrm{~g} \mathrm{C} \mathrm{m}^{-2} \mathrm{y}^{-1}$, respectively. The overall seasonal pattern of $R_{S}$ in TL and UTC followed seasonal changes in soil temperature (see Fig. 1, 4). The mean instantaneous rates of $R_{\mathrm{S}}$ in TL and UTC were 3.25 and $3.89 \mu$

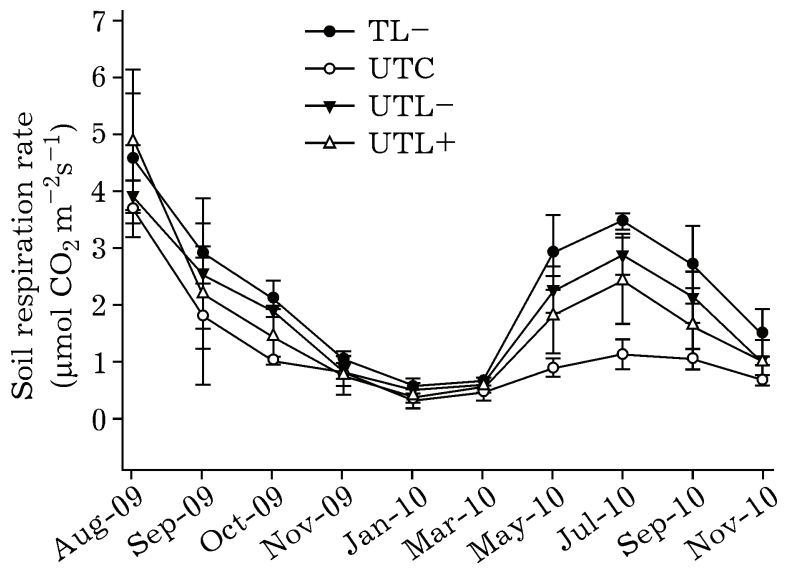

Fig. 4. Temporal and treatment effects of litter addition (UTL+), litter removal (UTL-) and trenching (TL) in relation to the control plots (UTC) on soil respiration rates (mean $\pm \mathrm{SE}$ of $\mathrm{x}$ replica) from August 2009 to December 2010

mol $\mathrm{CO}_{2} \mathrm{~m}^{-2} \mathrm{~s}^{-1}$, respectively. The difference between $R_{\mathrm{S}}$ in UTC and TL in the second year was much higher than that of the first year.

\section{Variation in soil respiration related to temperature and soil water content}

The temperature at a depth of $10 \mathrm{~cm}$ accounted for more than $60 \%$ of the variation in $\mathrm{R}_{\mathrm{S}}$ in the UTL+, UTC, UTL- and TL treatments (Fig 5). However, the correlation between $R_{S}$ and temperature decreased by $16 \%$ for $R^{2}$ in the UTL- and TL treatments. $\mathrm{Q}_{10}$ values were $2.72,3.46,4.85$, and 6.36 in UTL+, UTC, UTL-, and TL, respectively; trenching and litter removal both increased $\mathrm{Q}_{10}$, while litter addition decreased it.

The exponential temperature model explained most of the variation in $R_{S}$. The soil moisture functions (Eq. 4, 5) performed poorly for UTL+, UTL-, and TL treatments, and performed well for UTC. The regression model of soil temperature together with soil moisture also described $R_{\mathrm{S}}$ well.

\section{Effects of environmental factors on soil respiration}

It is commonly accepted that temperature is the major factor controlling $R_{\mathrm{S}}$ [Raich, Schlesinger, 1992; Lamberty, Thomson, 2010]. Our results also showed a strongly exponential pos- 

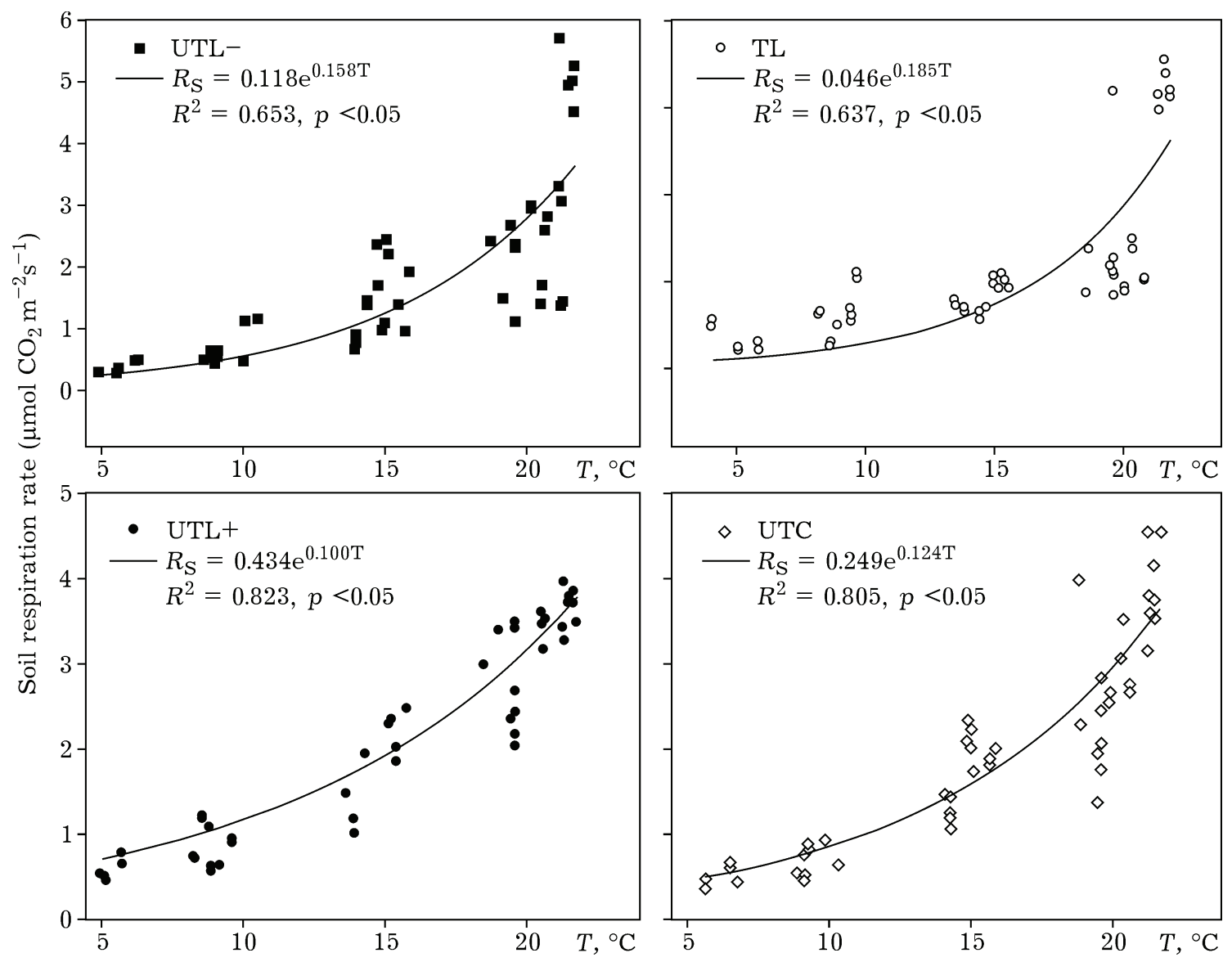

Fig. 5. Annual soil respiration rates

itive correlation between $R_{S}$ and soil temperature (Fig. 6). This finding is consistent with those of previous studies from tropical forests [Raich, Schlesinger, 1992; Schaefer et al., 2009]. The $Q_{10}$ values have commonly been used as an indicator of soil temperature sensitivity. In our study, the $Q_{10}$ values corresponding to the treatments occurred in the following order: UTL $<\mathrm{UTC}<\mathrm{UTL}<\mathrm{TL}$. It is worthwhile to note

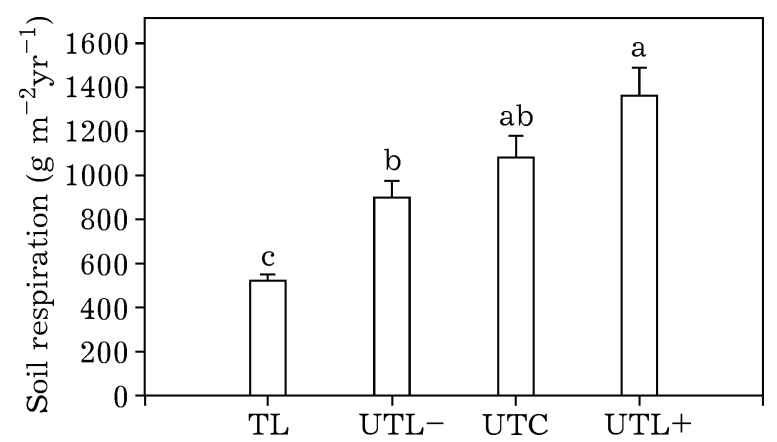

Fig. 6. Annual soil respiration rates for the 4 treatments. Columns with different low case letters are significantly different at $p<0.05$ that the apparent $Q_{10}$ value increased after trenching and litter removal, and decreased after litter addition; this indicates that litter removal enhanced the temperature sensitivity of $R_{\mathrm{S}}$. Overall, there is still uncertainty about the mechanisms mediating the variability of $\mathrm{Q}_{10}$. The $\mathrm{Q}_{10}$ value may be affected by a range of factors, including soil water availability, temperature range, soil depth, substrate quality, and microbial activities [Xu, Qi, 2001; Wang et al., 2006]. A girdling experiment in a Scott pine forest of Sweden suggested that bulk $R_{S}$ was more sensitive to that of tree root [Bhupinderpal et al., 2003].

Soil water availability is another important factor influencing $R_{S}$ at the ecosystem level [Raich, Schlesinger, 1992; Davidson et al., 1998; Law et al., 2001]. However, except for UTC, the correlation between $R_{S}$ and soil moisture was relatively poor in the treatments. That is perhaps a result of the plentiful rainfall at the research site; because of this, tree root activities were seldom limited by soil water availa- 
bility, soils seldom underwent prolonged drought, and the seasonal variation in soil moisture did not limit the activities of microbes most of the time, as reported by Zhang et al. [2001].

\section{Litter change and soil respiration}

A global dataset indicated that $\mathrm{C}$ released by annual $R_{S}$ is, on average, three times higher than that contained in annual litterfall [Raich, Tufekcioglu, 2000]. Our result showed that C release by annual $R_{S}$ was $1.26,2.16,2.61$, and 3.28 times higher than that contained in litterfall in the TL, UTL-, UTC, and UTL+ plots, respectively. The $17.29 \%$ reduction in $R_{S}$ observed in UTL- is similar to the $20 \%$ decrease in an old-growth, moist lowland tropical forest in Panama after one year of litter removal [Sayer et al., 2007], but is lower than the $47.15 \%$ decrease observed after 3 years of litter removal in a subtropical moist forest in the Ailao Mountains Nature Reserve forest in China [Schaefer et al., 2009]. The decrease that occurred during our study could be attributed principally to a reduction in heterotrophic respiration because of the withdrawal of fresh substrate, since there were no significant differences in soil temperature or soil water content between the treatments.

The addition of plant litter increased soil respiration by $25.83 \%$ (see Fig. 6). About $8 \%$ of the increase in $R_{S}$ in the UTL+ treatment was the result of litter addition, and the decrease in $R_{S}$ in the UTL- treatment that resulted from litter removal suggests that aboveground litter has a priming effect on $\mathrm{R}_{\mathrm{S}}$ [Sayer et al., 2007; Dilly, Zyakun, 2008]. The priming effects of litter addition are also reported in a large number of studies [Sayer et al., 2007; Fontaine et al., 2007; Crow et al., 2009; Schaefer et al., 2009]. After 2 years of treatment in a tropical rain forest, Leff et al. [2012] found that annual $\mathrm{R}_{\mathrm{S}}$ was increased by approximately $15 \%$ in the litter addition plots, but decreased by $22 \%$ in the litter removal plots. Li et al. [2004] found that annual $R_{S}$ decreased by approximately $51 \%$ after 7 years of litter removal in pine plantation and secondary forest plots in Puerto Rico. This suggests that litter addition, besides increasing the amount of readily degradable $\mathrm{C}$, may also cause substan- tial losses of $\mathrm{CO}_{2}$ from the soil [Sayer et al., 2007; Schaefer et al., 2009].

\section{Annual fluxes of soil respiration components}

In this study, the measured soil $\mathrm{CO}_{2}$ efflux rates from the UTC plot was within the range of reported values for subtropical forests [Hanson et al., 2000; Subke et al., 2006; Tan et al., 2013]. Hanson et al. [2000] summarized about 50 reports and calculated mean ratios of autotrophic respiration to total $R_{S}$ of 48 for forest ecosystems. In our study this ratio was 52 and therefore very similar. However, our value is much higher than those reported in other studies, for example for temperate beech/spruce mixed forest [30, Andersen et al., 2005], Coastal Douglas fir forest [35, Lalonde, Prescott 2007], and subtropical forest of Southwestern China [33, Schaefer et al., 2009].

At the beginning of plot trenching (early August of 2009), the difference between $R_{S}$ in UTC and TL was very small (see Fig. 4), however, as treatments progressed, the difference increased. One possible explanation for this phenomenon is that in August, the hottest month in Southwestern China, microbial activity was the highest and soil organic matter decomposed quickly, therefore $R_{S}$ was high. However, in the growing season of the following year, soil organic matter decomposition was almost complete and $R_{S}$ was reduced. Our results demonstrate that $R_{S}$ in the TL treatment was always smaller than that of the UTC treatment; this result is different from those of previous studies [e.g., Lee et al., 2003; Wang, Yang, 2007; Schaefer et al., 2009]. The reason for this may be that our study was conducted in the summer, and the high temperature promoted $R_{S}$ in all treatments. Trenching severed roots and reduced $R_{S}$ by $52 \%$ in the mature broadleaf forest in Southwestern China, which indicates the significance of autotrophic respiration in forest ecosystems.

In conclusion, our results demonstrate that there was a strongly exponential positive correlation between $R_{S}$ and soil temperature, while the correlation between $R_{S}$ and soil moisture was poor except UTC. Litter addition caused a decrease in $\mathrm{Q}_{10}$, but litter removal and 
trenching caused it to increase. Our results also indicate that litter addition had a priming effect on $R_{S}$, therefore human disturbance and global warming might have rapid and important consequences on soil respiration and may alter the mechanisms controlling soil $\mathrm{C}$ mineralization and stabilization in the subtropical forest.

This work was funded by the grants from the projects of strategic pilot of Chinese Academy of Sciences, Carbon budget certification and related issues response to climate change (No. XDA0505020406).

REFERENCES

Anderson J. M., Proctor J., Vallack H. W. Ecological studies in four contrasting lowland rain forests in GunungMulu National Park, Sarawak. 3. Decomposition processes and nutrient losses from leaf litter // J. of Ecol. 1983. N 71. P. 503-527.

Baldocchi D., Tang J. W., Xu L. K. How switches and lags in biophysical regulators affect spatial-temporal variation of soil respiration in an oak-grass savanna // J. Geophys. Res. 2006. N 111. G02008.

Bhupinderpal-Singh N. A., Ottosson L. M., Högberg M. N. et al. Tree root and soil heterotrophic respiration as revealed by girdling of boreal Scots pine forest: extending observations beyond the first year // Plant, Cell and Environment. 2003. N 26. P. 1287-1296.

Bond-Lamberty B., Wang C. K., Gower S. T. Contribution of root respiration to soil surface $\mathrm{CO}_{2}$ flux in a boreal black spruce chronosequence // Tree Physiology. 2004b. N 24. P. 1387-1395.

Crow S. E., Lajtha K., Bowden R. D. et al. Increased coniferous needle inputs accelerate decomposition of soil carbon in an old-growth forest // Forest Ecology and Management. 2009. N 258. P. 2224-2232.

Davidson E. A., Belk E., Boone R. D. Soil water content and temperature as independent or confounded factors controlling soil respiration in a temperate mixed hardwood forest. // Global Change Biol. 1998. N 4. P. 217-227.

Dilly O., Zyakun A. Priming effect and respiratory quotient in a forest soil

amended with glucose // Geomicrobiology Journ. 2008. N 25. P. 425-431.

Fontaine S., Bardoux G., Abbadie L. et al. Carbon input to soil may decrease soil carbon content // Ecol. Lett. 2004. N 7, P. 314-32.

Hanson P. J., Edwards N. T., Garten C. T. et al. Separating root and soil microbial contributions to soil respiration: a review of methods and observations // Biogeochemistry. 2000. N 48. P. 115-146.

Hibbard K. A., Law B. E., Reichstein M. et al. An analysis of soil respiration across northern hemisphere temperate ecosystems // Ibid. 2005. N 73. P. 29-70.

Högberg P., Singh B., Löfvenius M. O. et al. Partitioning of soil respiration into its autotrophic and heterotrophic components by means of tree-girdling in old boreal spruce forest // Forest Ecol. and Management. 2009. N 257. P. 1764-1767.
Högberg P., Read D. J. Towards a more plant physiological perspective on soil ecology. // Trends Ecol. \& Evolution. 2006. N 21. P. 548-554.

Houghton R. A., Goodale C. L. Effects of Land-Use Change on the Carbon Balance of Terrestrial Ecosystems // Ecosystems and Land Use Change, Geophysical Monograph Series. 2002. N 153. P. 85-98.

Janssens I. A., Lankreijer H., Matteucci G. et al. Productivity overshadows temperature in determining soil and ecosystem respiration across European forests // Global Change Biology. 2001. N 7. P. 269-278.

Kalbitz K., Meyer A., Yang R. et al. Response of dissolved organic matter in the forest floor to long-term manipulation of litter and throughfall inputs // Biogeochemistry. 2007. N 86. P. 301-318.

Lalonde R. G., Prescott C. E. Partitioning heterotrophic and rhizospheric soil

respiration in a mature Douglas-fir (Pseudotsuga menziesii) forest // Canad. Journ. of Forest Res. 2007. N 37. P. 1287-1297.

Lamberty B. B., Thomson A. Temperature-associated increases in the global soil respiration record // Nature. 2010. N 464. P. 579-582.

Law B. E., Kelliher F. M., Baldocchi D. D. et al. Spatial and temporal variation in respiration in a young ponderosa pine forests during a summer drought // Agricultural and Forest Meteorology. 2001. N 110. P. 2743.

Lee X. H., Wu H.-J., Sigler J., Oishi C., Siccama T. Rapid and transient response of soil respiration to rain // Global Change Biol. 2004. N 10. P. 1017-102.

Leff J. W., Wieder W. R., Taylor P. G. et al. Experimental litterfall manipulation drives large and rapid changes in soil carbon cycling in a wet tropical forest // Ibid. 2012. N 18. P. 2969-297.

Li Y. Q., Xu M., Sun O. J. et al. Effects of root and litter exclusion on soil CO2 efflux and microbial biomass in wet tropical forests // Soil Biol. \& Biochem. 2004. N 36. P. 2111-2114.

Marland G., Boden T. A., Andres R. J. Global, Regional, and National $\mathrm{CO}_{2}$ Emissions Trends: a Compendium of Data on Global Change. Tennessee: ORNL CDIAC, Oak Ridge National Laboratories, 2000.

Ohashi M., Gyokusen K., Saito A. Contribution of root respiration to total soil respiration in a Japanese cedar (Cryptomeria japonica D. Don) artificial // Ecol. Res. 2000. N 15. P. 323-333.

Park J. H., Kalbitz K., Matzner E. Resource control on the production of dissolved organic carbon and nitrogen in a deciduous forest floor // Soil Biol. \& Biochem. 2002. N 34. P. 813-822.

Peng S. L., Hao Y. R. The dynamic of forest root and its distribution during succession // Acta Scientlarum Naturalium Universitatis Sunyatseni. 2005. Vol. 45, N 5. P. 65-69.

Raich J. W., Potter C. S., Bhagawati D. Interannual variability in global soil respiration, 1980-94 // Global Change Biol. 2002. N 8. P. 800-812.

Raich J. W., Schlesinger W. H. The global carbon dioxide flux in soil // Tellus. 1992. N 44. P. 81-99.

Raich J. W., Tufekcioglu A. Vegetation and soil respiration: correlations and Controls // Biogeochemistry. 2000. N 48. P. 71-90.

Ryan M. G., Law B. E. Interpreting, measuring, and modeling soil respiration // Ibid. 2005. N 73. P. 3-27. 
Sayer E. J., Powers J. S., Tanner E. V. J. Increased litterfall in tropical forests boosts the transfer of soil $\mathrm{CO}_{2}$ to the atmosphere // PLoS ONE. 2007. Vol. 2, N 12. e1299. doi:10.1371/journal.pone.0001299.

Sayer E. J. Using experimental manipulation to assess the roles of leaf litter in the functioning of forest ecosystems // Biol. Rev. 2006. N 81. P. 1-31.

Sayer E. J., Tanner E. V. J., Cheesman A. W. Increased litterfall changes fine root distribution in a moist tropical forest // Plant and Soil. 2006. N 281. P. 5-13.

Schaefer D. A., Feng W. T., Zou X. M. Plant carbon inputs and environmental factors strongly affect soil respiration in a subtropical forest of southwestern China // Soil Biol. \& Biochem. 2009. N 41. P. 10001007.

Schlesinger W. H., Andrews J. A. Soil respiration and the global carbon cycle // Biogeochemistry. 2000. N 48. P. 7-20.

Schimel D. S., House J. I., Hibbard K. A. et al. Recent patterns and mechanisms of carbon exchange by terrestrial ecosystems // Nature. 2000. N 414. P. 169172.

Sheng H., Yang Y. S., Yang Z. J. et al. The dynamic response of soil respiration to land-use changes in subtropical China // Global Change Biol. 2010. N 16. P. 1107-1121.

Subke J. A., Inglima I., Cotrufo M. F. Trends and methodological impacts in soil $\mathrm{CO}_{2}$ efflux partitioning: a metaanalytical review // Ibid. 2006. N 12. P. 921943.

Sulzman E. W., Brant J. B., Bowden R. D. et al. Contribution of aboveground litter, belowground litter, and rhizosphere respiration to total soil CO2n efflux in an old growth coniferous forest // Biogeochemistry. 2005. N 73. P. 231-256.

Tang X. L., Liu S. G., Zhou G. Y. et al. Soil - atmospheric exchange of $\mathrm{CO}_{2}, \mathrm{CH}_{4}$ and $\mathrm{N}_{2} \mathrm{O}$ in three subtropical forest ecosystems in southern China // Global Change Biol. 2006. N 12. P. 546-560.

Tan Z. H., Zhang Y. P., Liang N. S. et al. Soil respiration in an old-growth subtropical forest: patterns, components, and controls // J. Geophys. Res.: atmospheres. 2013. N 118. P. 1-10.

Townsend A. R., Cleveland C. C., Houlton B. Z. et al. Multi-element regulation of the tropical forest carbon cycle // Frontiers in Ecol. and the Environ. 2011. N 9. P. 9-17.

Trumbore S. E. Carbon respired by terrestrial ecosystemsrecent progress and challenges // Global Change Biol. 2006. N 12. P. 141-153.

Wang C. K., Yang J. Y., Zhang Q. Z. Soil respiration in six temperate forests in China // Ibid. 2006. N 16. P. 2103-2114.

Wang C. K., Yang J. Y. Rhizospheric and heterotrophic components of soil respiration in six Chinese temperate forests // Ibid. 2007. N 13. P. 123-131.

Wieder W. R., Cleveland C. C., Townsend A. R. Controls over leaf litter decomposition in wet tropical forests // Ecology. 2009. N 90. P. 3333-3341.

$\mathrm{Xu}$ M., Qi Y. Spatial and seasonal variations of $\mathrm{Q}(10)$ determined by soil respiration measurements at a sierra Nevadan forest // Global Biogeochem. Cycles. 2001. N 15. P. 687-696.

Zhang X. J., Xu H., Chen G. X. Major factors controlling nitrous oxide emission and methane uptake from forest soil // J. Forestry Res. 2001. N 12. P. 239-242. 